\title{
Nature of Exploitation of Forest Resources Towards the Welfare of the Customary Law Community in Maluku Province (Perspectives on Pancasila Law and Legal Pluralism)
}

\author{
Eric Stenly Holle ${ }^{* 1} \quad$ Abrar Saleng $^{2} \quad$ Aminuddin Salle $^{3} \quad$ A.Suryaman Mustari Pide ${ }^{2}$ \\ 1.Students of the Doctoral Program at the Faculty of Law, Hasanuddin University and Lecturers at Pattimura \\ University, Ambon \\ 2.Professor in the Field of Legal Sciences, Faculty of Law, Hasanuddin University, as a Promoter \\ 3.Professor in the Field of Legal Studies, Faculty of Law, Hasanuddin University, as Co-Promoter
}

\begin{abstract}
Philosophically, Pancasila gives power to the state to intervene in people's lives (welfare state) in order to realize social justice and welfare. If it is related to forestry, then state intervention is elaborated in the form of state control over the exploitation of forest resources with the aim of maximizing people's prosperity. Maluku Province is rich in natural resources including forests, but its management and exploitation paid little attention to the existence and rights of local customary law communities, forest concession licenses to corporations through Forest Concession Rights granted by the government through laws and regulations in the forestry sector. positive contribution to the existence of indigenous and tribal peoples, meanwhile in Indonesia where heterogeneous (plural) communities cannot necessarily ignore the rights and authority of indigenous and tribal peoples towards forest and other agrarian resources through state law.
\end{abstract}

Keywords: Pancasila, Legal Pluralism, Forest Exploitation, Customary Law Communities

DOI: $10.7176 /$ JLPG/95-11

Publication date:March $31^{\text {st }} 2020$

\section{A. INTRODUCTION}

Indonesia is the largest Archipelagic State in the world, has 17,508 large and small islands, land area of 1.937 million $\mathrm{km} 2$, sea area of 5.8 million $\mathrm{km} 2$ with the longest coastline in the world. The geographical position between the two continents (Asia and Australia) and the two oceans (the Indies and the Pacific) crossed by the equator is a gift from God to the Indonesian people with its abundant natural resources. Indonesia's natural resources come from agriculture, forestry, marine and fisheries, livestock, plantations as well as mining and energy.

Natural resources have a very strategic role in supporting national development because from the management of natural resources it will generate foreign exchange for the country, as the largest contributor in the State Budget (APBN), providing benefits to the Regional Budget (APBD) and increase the economic level of people who are in or around the area of natural resources. The philosophical basis of natural resources and the norms that govern them are providing legal certainty and improving people's welfare.

As an island province consisting of small islands, Maluku province has unique characteristics. Maluku has been known since ancient times as a land of spices so that it invited many countries who came to take it. Besides that Maluku also has special potential and is rich in other natural resources in the form of mining, sea and forest. Forests in Maluku have various types of endemic flora and fauna which have high values and are preserved until now and provide many benefits to the community. Besides having abundant natural resources, from the social and cultural aspects of Maluku it is also known for its unique and unique culture seen from various kinds of ceremonies or traditional rituals, pela and gandong traditions and so on, the customary law community in Maluku in maintaining its function, the carrying capacity and sustainability of forest resources still use their local wisdom. Likewise with the forests that are believed by the Maluku traditional law community as a home for their lives to live and earn a living. Place to carry out various activities in supporting economic, social, cultural and religious life such as hunting, gathering, performing traditional rituals and so on.

The comfort and security of indigenous and tribal peoples in Maluku who live in or around the forest for a long time have begun to be disturbed by various investment activities in the forestry sector with various permits issued by the government to corporations (holders of forest concessions) because of the need for forest resources more increasing. The implication is that the area and potential of the forest are declining due to forest exploitation activities, so what arises is the socio-cultural, economic and environmental problems of the local community such as restrictions on community access to forests, illegal logging, illegal occupation of customary forest areas, damage to flora and forest fauna and the excesses that arise is the existence of indigenous and tribal peoples in Maluku and their rights being neglected, the distribution or distribution of forest benefits is also not fully felt by indigenous peoples, because forest exploitation is still oriented towards economic interests (timber management) without regard to justice and sustainability of functions, carrying capacity of forests and the environment for future 
generations.

Pancasila has been mutually agreed upon as a way of life and as the basis of the state. Theoretically, the way of life of the nation is always based on values that are meta-juridical, based on values and morality that are mutually agreed upon. These meta-juridical values clearly cannot have legal force. In order to be legally binding, these values must be contained in legal norms whose determination is based on good ethical and moral values.

Philosophically, Pancasila gives power to the state to intervene in people's lives (welfare state) in order to realize social welfare. If it is related to the field of natural resources, then state intervention is elaborated in the form of state control over natural resources with the aim of maximizing the prosperity of the people. Indonesia does not use the concept of ownership in the management and exploitation of natural resources, but the concept of control in accordance with Article 33 of the 1945 Constitution. However, natural resources are not without owners, ${ }^{1}$ the owners are the Indonesian Nation, but the management is carried out by the state as the largest organization in a nation.

It should be noted that Indonesia is a state of pluralism that enforces laws established by the state and laws that live and develop in society (the living law). In the perspective of legal science, good law is a law that is created based on the law that lives in the community (the living law) as stated by Eugen ${ }^{2}$ Erlich who argues that "The development of law is centered on society itself, not on formation by the state, the judge's decision or in the development of legal science ". Both types of law when confronted usually lead to conflicts from the parties concerned, especially in the implementation of exploitation of forest resources considering that in the era of globalization, the concept of exploiting sustainable forest resources has developed to become very complex.

State legitimacy in the context of control of forest resources contained in Law Number 41 of 1999 concerning forestry and its derivatives that are centralistic (forcing, exclusive, hierarchical, systematic and uniformly applied) and apply from the top downward without top downward pay attention to and clearly ignore the applicable law in the community that is customary law to be one of the causes of prolonged conflict in the forestry sector between the government, holders of forest concessions with indigenous and customary law communities so that it has several times been tested by the Constitutional Court. In the implementation of several Constitutional Court Decisions related to the Customary Law Community such as the Constitutional Court Decree Number 35 / PUU$\mathrm{X} / 2012$ related to forest status also experienced its own problems, especially for local governments in terms of recognition of customary law communities and the determination of customary forests so that there are still many conflict after the Constitutional Court ruling that led to the criminalization of indigenous peoples who have a weak position before the state when trying to maintain their living space, namely forests that have been preserved and preserved from generation to generation based on local wisdom.

The state is always seen as an organization of power of all people in the sense of personification of all people who have the authority to regulate matters relating to forest resources. Is this really the power of the state so that it can be justified in shifting the position of citizens both individuals and indigenous peoples? For this reason, Pancasila as a philosophical basis for answering it. In the context of abstract law (metajurudis) Pancasila is translated as general legal principles (basic legal principles or elements of rechtsbeginselen), which form the basis of all legal order. One form of general legal principles is the balance of rights and obligations. In the context of the exploitation of forest resources, it is intended that there is a need to balance the needs and interests of stakeholders, namely the government, HPH permit holders and indigenous peoples who are just and sustainable in terms of economic, socio-cultural and environmental aspects in order to achieve community welfare. Based on the background of the above thought, the formulation of the problems that will be examined in this paper are: 1. How is the Pancasila Law (rechts idee) Construction on the Rights of Indigenous Peoples in the Exploitation of Forest Resources? 2. How is the Exploitation of Forest Resources in Maluku Against the Welfare of Customary Law Communities?

\section{B. RESEARCH METHODS}

THis research is a type of normative legal research that is legal research whose research objects include statutory provisions and legal documents that are documentary in nature. The approach used in this study is the statute approach, the approach, ${ }^{3}$ and the conceptual approach, ${ }^{4}$

\footnotetext{
${ }^{1}$ Pasal 1 Undang-Undang Pokok Agraria Nomor 5 Tahun 1960

${ }^{2}$ Eugen Ehrlich, Fundamental Principles of The Sociology of Law, Walter L. Moll trans, 1936, p. xi

${ }^{3}$ La Ode Angga, M. J. Saptenn, The Formulation Of Green Open Space In The Regional Regulation Of Spatial Planning Of Maluku Province, International Journal Of Scientific \& Technology Research Volume 8, Issue 10, October 2019 Issn 2277-8616 3370 Ijstr@2019 Www.Ijstr.Org. p. 1 .

${ }^{4}$ Mahmud, Marzuki Peter. 2009. Penelitian Hukum. Jakarta: Kencana Prenada Media Group, p. 2.
} 


\section{THEORETICAL BASIS}

\section{Concept of Customary Law Communities}

The word "adat" comes from Arabic which means habit. According to A. Suriyaman Mustari Pide, ${ }^{1}$ the occurrence of law stems from the person who creates "personal habits" and then imitated by other people, then gradually the habit becomes "custom" which must apply to all members of the community, so that it becomes "customary law" so that customary law is a custom that is accepted and must be implemented in the community concerned. The term customary law is a translation of the term in Dutch adatrecht which was first introduced by Snouck Hurgronye. ${ }^{2}$ Meanwhile, the definition of customary law according to C. van Vollenhoven is the overall rules of positive behavior which on the one hand have sanctions (law) and on the other hand in a state not codified positive behavior has a legal meaning which is declared to apply here now. ${ }^{3}$

From the understanding of customary law put forward by the customary law experts above it substantially provides an understanding that customary law is a law that is alive, maintained, developing in accordance with the times, unwritten, carried out on the basis of mutual agreement and gaining the legitimacy of the "ruler" of custom, which is binding and regulate and be obeyed by all existing customary law communities. Customary law aims to create order, peace and promote community welfare. The term indigenous peoples is a translation of rechtsgemeenschap or some literature calls it adatrechtsgemenschap. The concept of indigenous and tribal peoples was first introduced by Cornelius van Vollenhoven. ${ }^{4}$ In his book entitled Beginselen en Stelsel van het Adatrecht, ter Haar formulates customary law communities, as follows: ${ }^{5}$

"... geordende groepen van blijvend met eigen bewind en eigen materieel en immaterieel vermogen characters" (free translation: "... regular groups that are subject to self-government which have material and immaterial objects").

Indigenous and tribal peoples' unity is another term used in legislation that accommodates differences in the use of "indigenous and tribal peoples". The term indigenous people is a translation of "indigenous peoples" in English that should be translated into "indigenous people". In Indonesia the term indigenous people is not used because the use of indigenous people can produce sharp polemics, and can even be a source of conflict.

Soekanto said that the customary law community was a legal subject, because it was autonomous, which was later called village autonomy; it means that the legal community carries out legal actions, for example making decisions which are binding on the community members, conducting judicial proceedings, regulating land use, inheriting and so on. ${ }^{6}$ Indigenous and tribal peoples are human social communities that feel united because they are bound by common ancestors and / or certain regions, inhabit certain areas, own their own wealth, be led by one or several people who are considered to have authority and power, and have values as a way of life and has no desire to separate. ${ }^{7}$

According to Maria R. Ruwiastuti, indigenous peoples have 4 (four) characteristics, namely (1) those who have origins in community and territorial life; (2) has its own customary legal system, cultural values and ideology; (3) having customary institutions whose decision-making processes are democratic and not based on feudalism; and (4) controlling and possessing territorial and typical patterns of utilization of agrarian resources for generations.

According to F.D. Holleman in the book De commune Trek in het Indische Rechtsleven, there are 4 General traits of indigenous peoples, namely Religious Magical, Communal / Togetherness, Cash and Concrete / Visual. A brief explanation of this is: ${ }^{8} 1$ ) Religious magical nature is interpreted as a mindset based on religiosity, namely people's beliefs about the existence of something that is sacred. 2). Communal nature. Indigenous and tribal peoples have the assumption that each individual, community member is an integral part of the community as a whole. Individual interests are aligned with the interests of society because there are no individuals who are separated from the community. 3). Cash properties. This trait implies participation, especially in terms of fulfilling achievement. Each achievement fulfillment is always accompanied by contra achievement which is given immediately / instantaneously. 4). Concrete nature. This trait is interpreted as a characteristic that is completely clear or real, showing that every legal relationship that occurs in society is not carried out secretly or vaguely. ${ }^{9}$

Ter Haar explained the characteristics of indigenous and tribal peoples, namely the existence of regular human unity; settling in a certain area; have rulers; has tangible or intangible wealth, where members of each unit experience life in society as natural according to nature; and the existence of law that is obeyed or obeyed in the

\footnotetext{
${ }^{1}$ A. Suriyaman Mustari Pide, Hukum Adat, Dulu, Kini, dan Akan Datang, Penerbit Buku Pelita Pustaka, 2009, p. 3.

${ }^{2}$ Bushar Muhammad, Asas-asas Hukum Adat Suatu Pengantar, cet.ke 11, Pradnya Paramita, Jakarta, 2002. p. 1.

${ }^{3}$ Dominikus Rato, Hukum Adat (Suatu Pengantar Singkat Memahami Hukum Adat di Indonesia), Penerbit laksbang pressindo, Yogyakarta, 2011, p. 11

${ }^{4}$ Rikardo Simarmata, 2006, Pengakuan Hukum Terhadap Masyarakat Adat di Indonesia, UNDP Regional Centre in Bangkok, Jakarta. p. 23

${ }^{5}$ B. ter Haar Bzn, Beginselen en Stelsel van het Adatrecht, Gronongen, J.B. Wolters. 1950, p 16.

${ }^{6}$ Rikardo Simarmata, 2006, Pengakuan Hukum Terhadap Masyarakat Adat di Indonesia, UNDP Regional Centre in Bangkok, Jakarta. p. 23

S. Soekanto, Beberapa Permasalahan Hukum Dalam Kerangka Pembangunan di Indonesia, UI-Press, 1983, Jakarta, p..3

${ }^{8}$ Dominikus Rato, Hukum Adat di Indonesia; Suatu Pengantar, Laksbang Justitia Surabaya, 2014, p. 82.

${ }^{9}$ Otje Salman Soemadiningrat, Rekonseptualisasi Hukum Adat Kontemporer, Alumni, Bandung 2002, p. 29-30
} 
customary law community. ${ }^{1}$

\section{Concept of Welfare State}

In a formal legal state, the duty of the state is to carry out the statutory regulations to carry out order or better known as the natcwackerstaats night watch state. While in a material law state, the duty of the state is not only to maintain order, but also to achieve the welfare of the people to achieve justice for the welfare state.

The main characteristic of a welfare state is the emergence of a government obligation to realize public welfare for its citizens. In other words, the teaching of welfare state is a concrete form of shifting the principle of limiting the role of the state and government in the economic and social sectors of society (staatsonthounding) due to the failure of the concept of a night watch state (legal state) to become a staatsbemoeienis which requires the state and the government to be actively involved in economic life and social community, as a step to realize public welfare or service for the public (public service) besides maintaining order and security (rust en order).

E. Utrecht which states that the scope of the welfare state's duty is to maintain security in the broadest sense up to social security in all fields of people's lives. The government must actively participate in social interaction so that social welfare for all people can be maintained. Therefore the state administration is tasked with organizing public welfare (bestuurszorg)

The concept of a welfare state according to Bagir Manan is "The state or government which is not merely a guardian of security or public order but also as the main bearer of responsibility in realizing social justice, general welfare, and as much as possible for the prosperity of the people. ${ }^{2}$

The concept of a modern / material legal state (welfare state) is adopted by Indonesia, with the aim of creating a just and prosperous society both spiritually and materially based on the Pancasila and the 1945 Constitution so that it is called the Pancasila State of Law. In the fourth paragraph Opening of the 1945 Constitution explicitly stated that:

"Protect all Indonesian people and all Indonesian blood and to promote public welfare, educate the nation's life, and participate in carrying out world order based on independence, eternal peace and social justice ..."3

In relation to the exploitation of forest resources aimed at the welfare of the community, especially customary law communities, in line with the objectives of the Indonesian state, the main characteristics / rule of law required is the element of all stakeholders' actions, both the government, forest concession permit holders, and the customary law community in a balanced manner, social justice and sustainable both in economic, socio-cultural and environmental aspects. For this reason, commitment is needed not only from a normative perspective but also ethically and morally from these stakeholders to carry out exploitation of forest resources that contribute to national interests, especially for the welfare of indigenous and tribal peoples.

\section{Concept of Legal Pluralism}

The understanding of legal pluralism in statutory regulations is not found. To understand legal pluralism it is necessary to explain the views of experts. Lawrance M Friedman ${ }^{4}$ argues that legal pluralism means "The existence of different legal systems or cultures in a single political community". According to Griffiths ${ }^{5}$ legal pluralism is "a condition that occurs in any social area where all community actions in the region are governed by more than one orderly law". Meanwhile Paul Schiff Berman ${ }^{6}$ expressed his opinion about legal pluralism as "Those situations in which two or more non-state normative systems occupy the same social fields and must negotiate the resulting hybird legal space" in this sense pluralism is constructed as a state in which two or more legal norms apply in social life and can be negotiated to produce two types of legal systems in an area.

According to Muhammad Bakri, ${ }^{7}$ legal pluralism is "applying a variety of (more than one) specific laws to all the people of a particular country" This view analyzes legal pluralism from the aspect of the application of legal norms in a country which are classified into two types namely: 1) determined law by the state and 2) living laws that develop in society.

Thus it can be concluded that legal pluralism is the enactment of two or more legal systems in a society within a country. There are laws made by the state (state law) and there are laws that apply and are determined by the community itself, such as customary law, religious law and others. From this explanation can be formulated the understanding of the theory of legal pluralism that is the theory that studies and analyzes the diversity of applicable

\footnotetext{
${ }^{1}$ Ter Haar, Asas-asas dan Susunan Hukum Adat, terjemahan oleh K.NGSubekti Poesponoto, Pradnya Paramita, Jakarta, 2001, p..16

${ }^{2}$ Bagir Manan, Dasar-Dasar Sistem Ketatanegaraan RI Menurut UUD 1945, Makalah dalam Ceramah Ilmiah pada Mahasiswa Pascasarjana Unpad TA 1994/1995, Unpad, Bandung, 3 September

${ }^{3}$ Sjachran Basah, Eksistensi dan Tolak Ukur Badan Peradilan Administrasi di Indonesia, Cetakan kedua, Alumni, Bandung, 1983 , p.11

${ }^{4}$ Lawrence M Friedman, Sistem Hukum Perspektif Ilmu Sosial (A Legal Sistem A Social Science Perspective). Diterjemahkan oleh M. Khozim, Nusa Media, Bandung, 2009, p. 257)

${ }^{5}$ Jhon Griffiths, Memahami Pluralisme Hukum, Sebuah Deskripsi Konseptual dalam Pluralisme Hukum Sebuah Pendekatan Interdisipliner, Penerjemah Andri Akbar dkk, Huma, Jakarta, 2005, p. 69-71

${ }^{6}$ Paul Schiff Berman, Federalism and International Law Througt the Lens of Legal Pluralism, Missouri Law Review, Vol 7, 2008, p. 121

${ }^{7}$ Muhammad Bakri, Unifikasi dalam Pluralisme Hukum Tanah di Indonesia (Rekonstruksi Konsep Univikasi Dalam UUPA), Kertha Patrika, vol 33 No 1, 2008, p. 2
} 
laws and applied in social life, national and state life. The object of study applies and is applied in social life, especially civil law. In legal pluralism that applies a variety of laws, it is not possible to have legal unification (uniformity of the law) because it will cause injustice because the Indonesian people are still plural in nature.

\section{DISCUSSION}

\section{Pancasila Construction As a Philosophical Foundation for Exploitation of Forest Resources}

In actual terms in the present context, there is an increasingly wide gap between the ideals of the Pancasila and the reality of their earth. That wide gap between ideality and the reality of Pancasila is the source of the national crisis today. Difficult to find guiding stars that give birth to common ground, fulcrum and destination. If Pancasila really wants its supernatural powers, Pancasila must become an ideological praxis that has real power in making a fundamental overhaul in the material-mental-political domain as a catalyst for the realization of national ideals. To be able to cultivate Pancasila, the Indonesian people must have three powers (trisakti) in the three areas of social change, namely sovereignty in politics, self-reliance in the economy and personality in culture. ${ }^{1}$

Mental-cultural transformation is directed so that the Indonesian people can personality in culture by realizing a religious society that is humane, egalitarian, independent, trustworthy and free from materialism-hedonism; and able to establish unity (mutual cooperation). The basic steps are mainly the principles contained in the first, second and third precepts. Political transformation is directed so that the Indonesian nation can be sovereign in politics through a united oriented democracy (family state) and justice (welfare state). Its basic footing is mainly the principles contained in the fourth precept. Material (economic) transformation is directed so that the Indonesian nation can be independent (independent) in the economy, by creating an independent economy that is just and prosperous; based on the business of help and assistance and state control over the important branches of production which control the lives of many people, as well as over the earth, water and natural resources contained therein; while providing opportunities for private property with social functions. Its basic footing is mainly the principles contained in the fifth precept. The three realms of social transformation based on the Pancasila can be distinguished but cannot be separated from one another needing synergistic interlocking. All three individually or simultaneously, directed to achieve national goals based on Pancasila. ${ }^{2}$

As a scientific discipline, Pancasila philosophy has a scientific building that refers to three dimensions if related to the exploitation of forest resources, namely:

a. The ontological dimension. Pancasila Ontology explores the nature of Pancasila values in the natural universe of human existence. The ontological dimension refers to the "deepest structure of meaning" which is the substance of the Pancasila that makes the basis of this state. The structure of the deepest meaning is in the lebenswelt of national life to be the root of the Pancasila idea. "The deepest structure of meaning" is the will to seek a common ground (agreement) in bringing together happiness (altroublesh al-ammah, bonnum comune) in a pluralistic national society. The meeting point is based on five fundamental values (Pancasila), one of the derivatives of its vision, namely a fair and prosperous sovereign life in the context of legal pluralism, the position of customary law as living law in the community must obtain institutional strengthening so that the existence of customary law communities and their rights including customary rights to customary forests are not arbitrarily occupied by the state

b. Epistemological dimension. The ontological dimension of public well-being is practiced at the epistemological level through synthetic ways of unifying ideas into new ideas called Pancasila. Thus the idea of divinity synthesizes with humanity, the idea of nationhood synergizes with democracy, the idea of social justice synthesizes with humanity and so on. This is what makes anthila in Pancasila read as a unit that relies and interlockes. In the exploitation of forest resources, the idea of social justice and humanity in Pancasila is the most relevant.

c. Axiological dimensions. The ontological and epistemological bases as described above are the basis for the axiological praxis of Pancasila which marks the practice of Pancasila values, both into the realm of action and institutional practices in the life of the nation and state. Pancasila axiology provides an operational framework in the fields of ethics and aesthetics as well as in ideology which is a form of praxis and the nature and way of thinking of Pancasila. In the context of exploitation of forest resources, the axiology of Pancasila relates to the value of social justice and equality and freedom of self-determination based on the theory of legal pluralism within the framework of the Unitary Republic of Indonesia.

Pancasila as a philosophy, view of life and state ideology contains its own legal conception (rechtidee). That the values of Pancasila as the soul of the nation occupy the position as the basic norms of the state (grundnorm / staatsfundamentalnorm) which are the source of all sources of law in Indonesia. Frans Magnis Suseno, called

\footnotetext{
${ }^{1}$ Yudi Latif, Wawasan Pancasila; Bintang Penuntun Untuk Pembudayaan,Cet I, Mizan Anggota IKAPI, Jakarta, 2018 p. 20

${ }^{2}$ Yudi Latif,...Wawasan Pancasila..Opcit, P. 21
} 
Pancasila as a value rooted in the traditions of Indonesian society. These values are shared by all communities in the archipelago. These values never directly contain a certain political policy, but rather as stars for the sailor who always becomes the orientation in taking all policies. ${ }^{1}$ Pancasila as the radiant soul of the nation must be seen as a meta-juridical form the highest legal norms, which Hans Kelsen called the Grundnorm (basic norms) ${ }^{2}$ and by Hans Nawiasky called the staatsfundamentalnorm (fundamental norms of the state).

For Indonesia, the values of Pancasila as the soul of the nation on which the nation is based have in turn become the basic norm. The community's agreement on the basis of the state that forms the basic norms of the state can be distinguished, but cannot be separated from the formulation of the country's constitution. Philosophically, the Preamble of the 1945 Constitution is a mode of vivendi (noble agreement) of the Indonesian people to live together in the bonding of a pluralistic nation. It can also be called a sign of birth which contains a statement of independence (proclamation) as well as self-identity and stepping steps to achieve the ideals of the nation and national goals. From a legal standpoint, the Opening of the 1945 Constitution containing Pancasila became the basis of state philosophy which gave birth to a legal ideal (rechtsidee) and the basis of its own legal system in accordance with the spirit of the Indonesian people themselves. Pancasila as the basis of the state becomes the source of all sources of law that provide legal guidance and overcome all statutory regulations. In such a position, the Preamble of the 1945 Constitution and the Pancasila which it contains becomes staatsfundamentalnorms or fundamental principles of state rules and cannot be changed by law, unless changes are made to the identity of Indonesia which was born in 1945.

In the dynamics of social life, according to Rudolf Stammler, the ideal of the law serves as a determinant of the direction for the achievement of the ideals of society. Although it is realized that the end point of the ideals of the community may not be fully achieved, but the legal ideal of providing positive benefits because it contains two sides with the ideals of the law can be tested positive applicable law and the ideals of law can be directed positive law as an effort to regulate the life of society and nation. Justice intended as a legal ideal is also an effort and act of directing positive law towards the ideals of law. Thus, a fair law is a law that is directed by the ideals of the law to achieve the goals of society. ${ }^{3}$ Furthermore Gustav Radbruch asserted that the ideals of law not only functioned as regulative benchmarks, namely that which tested whether a positive law was fair or not, but also simultaneously functioned as a constitutive basis, ie which determined that without a legal ideal, the law would lose its meaning as law. ${ }^{4}$

Arief Sidharta combines the functions of the ideal of law as suggested by Rudolf Stammler and Gustav Radbruch. According to him, the legal ideal serves as a general guiding principle, the norm of criticism (evaluation rules) and motivating factors in the administration of law (formation, application, enforcement and discovery) and legal behavior. ${ }^{5}$

Historically the five precepts of Pancasila were a (synthetic) blend of the diversity of beliefs, understandings and hopes that developed in this country. The first precepts are synthetic formulations of all religious and belief streams, the second precepts are synthetic formulations of all transnational social and humanitarian ideas and ideals. The third precept is a synthetic formula of ethnic diversity (aspiration-identity) into the unity of the nation, the fourth precept is the formulation of all notions of sovereignty. The fifth precept is a synthetic formula of all understandings of socio-economic justice.

Each Pancasila contains a theoretical-conceptual framework. The first precept, conceptualizing that divine values as a source of ethics and spirituality is considered important as the ethical foundation of state life. The second precept, conceptualizing that universal human values derived from God's law, natural law and human social nature are considered important as the ethical-political fundamentals of state life in world relations. The commitment of the humanitarian struggle is ideally universal but its historical-sociological implementation is particular. Universal values in the discourse of humanity must be classified with the treasury of local wisdom, global vision must be combined with the digestibility of local culture. The third precept conceptualizes that the actualization of the ethical values of humanity must first be firmly rooted in an environment of closer national relations before reaching further world associations. In internalizing the values of human unity, Indonesia is a national unity state that overcomes the understanding of groups and individuals. The fourth principle conceptualizes that the value of God, the value of humanity and the value of nationhood in their actualization must uphold the people's sovereignty in the spirit of consultation led by wisdom. In the vision of deliberative democracy,

\footnotetext{
${ }^{1}$ Frans Magnis Suseno, Berebut Jiwa BangsaI :Dialog, Perdamaian dan Persaudaraan, Kompas, Jakarta, 2006, P. 175

${ }^{2}$ Hans Kelsen, "General Theory of Law and State, Russell \& Russell", (New York : 1945) p.. 124, as where quoted in "Tinjauan Yuridis Kebijakan Tingkat Kandungan Dalam Negeri Dan Pajak Impor Dalam Industri Telepon Genggam Dikaitkan Dengan National Treatment”, Thesis Universitas Kristen Maranatha, P. 18

${ }^{3}$ Roeslan Saleh, Pembinaan Cita Hukum dan Penerapan Asas-Asas Hukum Nasional, Pusat Dokumentasi Hukum BPHN, Depertemen Kehakiman, Jakarta, 1995, p. 50

${ }^{4}$ Soejono Koesoemo Sisworo, Mempertimbangkan Beberaa Pokok Pikiran Pelbagai Aliran Filsafat Hukum Dalam Relasi dan Relevansinya Dengan Pembangunan/Pembinaan Hukum Indonesia, dalam 'Kumpulan Pidato Pengukuhan Guru Besar Fakultas Hukum Universitas Diponegoro, Semarang” dihimpun oleh : Soekotjo Hardiwinoto, Badan Penerbit Universitas Diponegoro, Semarang, 1995, p..121

${ }^{5}$ B. Arief Sidharta, Refleksi Tentang Struktur Ilmu Hukum, Mandar Maju, Bandung, 2000, p. 181
} 
democracy gains its authenticity in strengthening the people's sovereignty, when political freedom is intertwined with economic equality which enlivens the spirit of brotherhood within the framework of consensus-oriented unity (family state) and justice (welfare state). The fifth preceptualization conceptualizes that the value of God, humanity, nationality and populist values gain their full meaning as far as realizing social justice. On the one hand, the embodiment of social justice must reflect the ethical imperatives of the other four precepts. On the other hand the authenticity of the experience of the precepts of Pancasila can be rooted in the realization of social justice in the life of the nation.

Therefore according to the writer, that in the vision of social justice according to the five precepts of Pancasila if it is associated with the exploitation of the desired forest resources is a balance between meeting physical and spiritual needs, a balance between the role of humans as individual creatures (institutionalized in the market) and the role of humans as social beings (institutionalized in the state) and the balance between the fulfillment of civil and political rights with economic, social, cultural and environmental rights

2. Exploitation of Forest Resources Towards the Prosperity of Customary Law Communities in Maluku a. Rights and Authority of the Customary Law Community in Maluku Against Forest Resources

The forest for indigenous and tribal peoples in Maluku is the home they live in and where they live. For a long time, indigenous and tribal peoples in Maluku have run a sustainable and sustainable pattern of management and use of their forest products without destroying forests. The close relationship between the community and the forest can be seen from various activities such as hunting, gathering, and performing various traditional rituals. Forests are believed and believed to have magical and / or supernatural powers that affect the tranquility of their human lives. Supernatural or supernatural powers that appear in various forms of statement. There is a forest that cannot be entered by just anyone because it is believed that the forest is a sacred forest inhabited by the ancestors of the indigenous people such as the Nualu, Alune, Weimale, Huaulu tribes who are considered to be native to Seram Island or Ibu Island (nusa ina) which then radiates to other islands in Maluku. They are known as Alifuru which means "Early humans or early humans who inhabited the Maluku Islands".

The relationship between the Maluku traditional law community and forest resources is expressed through the views, behavior and local wisdom and utilization of the forest. Likewise the Maluku traditional law community residing on the islands, both large, medium, small and very small islands have the right and authority to preserve forest resources based on customary practices and regulations, local knowledge (local knowledge) and local culture. Within the boundaries of this cultural area, the Maluku traditional law community conducts daily activities to fulfill their daily needs by utilizing the forest.

From the perspective of the people of Maluku it can be understood that in utilizing forests, rights and obligations are reflected. This means that the right is the right of every person in the utilization of agrarian resources within the boundaries of his cultural territory, on the contrary the right is accompanied by an obligation to protect nature given by God Almighty to the ancestors and will continue to be passed on to future generations in a sustainable manner according to customary law applicable. Likewise, communities must preserve and protect a variety of plants and animals, helping to conserve and restore forest ecosystems because this is the place to build life. This cultural area is where human activities are in harmony with existing natural realities. ${ }^{1}$ The cultural area in the perspective of customary law is the environment in which the customary law community lives and lives its life by utilizing and cultivating nature which is referred to as the petuanan / ulayat area.

The basic philosophy of customary law of the Maluku people is a norm system that embodies the values, principles, structures, institutions, mechanisms, and strategies that grow, develop, and are adhered to by local communities, in their function as instruments to maintain orderly interactions between citizens and maintain regularity of behavior society (social order), regular relations with the creator and spirits that are believed to have supernatural powers (spiritual orders), and maintain regularity of people's behavior with the natural environment (ecological order).

In the mind of the Maluku religious customary community which has a religious-magical pattern, the universe is inhabited by spirits whose duty is to maintain the balance of structure and natural rhythm. If human behavior becomes greedy, destroys the balance of nature, or is no longer familiar and in harmony with the rhythm of nature, there will be disruption, disharmony, and shock in the universe, in the form of earthquakes, volcanoes, eruptions, plagues, diseases, floods, droughts, land landslides and others.

\section{b. Existence of Customary Law Communities in Maluku Post Constitutional Court Ruling Number 35 / \\ PUU-X / 2012}

The rights and authority of indigenous and tribal peoples, especially in Maluku, are increasingly threatened, especially in various laws and regulations that are still centralized in nature so that the existence of indigenous peoples and their rights has begun to be fought for by various elements of the community. The weakening of the existence of institutional customary communities by the state, especially in the forestry sector, is evident in Law Number 41 of 1999 Concerning Forestry while in the constitution in Article 18B Paragraph (2) it states that: "The

\footnotetext{
${ }^{1}$ Sony Keraf, Filsafat Lingkungan Hidup Alam Sebagai Sebuah Sistem Kehidupan, Kanisius, 2014, p. 155
} 
state recognizes and respects the customary law community units along with their traditional rights as long as they are alive and in accordance with the development of society and the principles of the Unitary State of the Republic of Indonesia, which is regulated in law. " The context of the article clearly shows the granting of conditional recognition and respect for indigenous and tribal peoples.

The regional authority to manage its own household based on the principles of decentralization and regional autonomy should give more space to the region and not centralized at the center. Likewise with the regulation of forest status which has triggered various conflicts in the region. Article 1 number 6 of Law Number 41 Year 1999 concerning Forestry states that "Customary forest is forest that is within the state forest area". Provisions on the status of customary forests were later changed through the Constitutional Court's decision Number 35 / PUU-X / 2012 to "Customary forests are forests that are within the territory of indigenous peoples". Before the entry into force of the Constitutional Court Decree No. 35 / PUU-X / 2012 proved to be a state tool, the government took over the customary community's customary forest rights in managing forests which were then turned into state forests, in addition to that in the name of state forest (adat) the permit was sold / submitted. to the owners of capital to be exploited without regard to the rights and local wisdom of the customary law community in the region. Not infrequently this triggers conflicts between indigenous and tribal peoples and entrepreneurs holding forest concession licenses for their customary forests.

After the decision of the Constitutional Court until now, the conflict does not necessarily abate, even the conflict in the forestry sector is mounting, especially in Maluku. Conflicts between forest concession holders and customary law communities that occur in Maluku are generally caused by several reasons, among others: lack of socialization, before operating companies did not ask permission in advance from the customary community leaders, illegal logging, the annexation of indigenous peoples' territories in Beyond block maps, permits that are not transparent are intended, there is no contribution to the community through corporate social and environmental responsibility (CSR), destruction of forests, water resources and ecology and often results in the criminalization of indigenous and tribal peoples who struggle to defend their customary territories. Here are some examples of cases that occurred in Maluku, among others:

1) PT Bintang Lima Makmur with Business Permit for the Utilization of Timber Forest Products in Natural Forest (IUPHHK-HA) with an area of work area of 24,550 Ha operating in the customary law area of the Nuaulu tribe of Central Maluku Regency;

2) PT Tanjung Wana Sejahtera with the Permit for the Utilization of Timber Forest Products (IUPHHK-HA) with an area of 37,654 hectares operating in five sub-districts which are customary law areas, namely in West Seram, Taniwel, Inamosol, Amalatu and Elpaputih sub-districts. West Seram Regency

3) CV Titian Hijrah Holders of Timber Utilization Permit (IPK) in Other Use Areas (GER) for the cultivation business of Nutmeg and Cocoa plantations with an area of 700 hectares that occupies the territory of the Sumeith Passinaru indigenous peoples

4) PT Nusa Ina Agro Tanah Merah Manise with a Timber Utilization Permit (IPK) located in an Other Use Area (APL) for an oil palm plantation business covering an area of 189.82 hectares has conducted illegal logging in the territory of the customary law community of the Osong State, Batuasa, and Gusalat, East Seram Regency.

5) CV. Sumber Berkat Makmur with a GPA permit at APL for the nutmeg cultivation in the region of the Sabuai customary law community in East Seram Regency

6) PT. Karya Jaya Berdikari with Permit for the Utilization of Timber Forest Products in Natural Forests (IUPHHK-HA) with an Area of Work: 93,980 hectares, which is located on Yamdena Island, precisely in Saumlaki, West Southeast Maluku Regency.

7) Three group companies: Menara Group (sugar cane commodity with an area of 457,740 ha), Aru Manise Group (Sugar Cane, Palm, Rubber Commodity covering 351,832 ha) and Nusa Ina Group (Sugar Cane, Palm and Sago HTI Commodities 549,151 ha) operating in the region customary law community in Aru Islands Regency.

The implication of the Constitutional Court Decree No. 35 / PUU-X / 2012 is that at the central level there is a need for cooperation and harmonization between related ministries so that overlapping authority does not occur, while at the regional level, local governments must issue regional regulations and head decisions regions regarding the recognition and protection of indigenous and tribal peoples and even regulations on the establishment of customary forests which include indicative maps of indigenous and tribal peoples that have been accommodated in the Minister of Environment and Forestry Regulation on Customary Forests and Private Forests.

The problem is that customary law communities do not have access to national law politics, especially in managing the recognition and protection of their existence in regional regulations or regional head decisions, especially if the local government pays little attention to the rights of indigenous peoples because of various interests with other parties, in this case holders HPH permits, so that indigenous and tribal peoples themselves find it difficult to obtain institutional recognition or support from local governments. For this reason, it is necessary to 
strengthen capacity and capability by various elements (stakeholders) so that the rights of indigenous and tribal peoples can be properly accommodated.

By looking at the reality that has existed so far in Maluku, it can be said that the customary law community is still underestimated by the state, even the local government itself, so that its rights, authorities and existence based on the constitution are ignored. The state does not play a role as a protector and protector of people whose positions are weak, even with various joint business patterns such as social forestry if it does not involve indigenous and tribal peoples in various processes, new problems may occur. The state through the activities of various corporations in the forestry sector only prioritizes the maximum economic benefits without regard to the sociocultural and environmental aspects, so the poverty rate in the Maluku islands is still high with a percentage of $17.69 \%$ in March 2019 Maluku is in the third position of the poorest in Indonesia after Papua, West Papua and East Nusa Tenggara is inversely proportional to the abundant potential of natural resources in Maluku.

Griffith argued that there are two types of legal order that apply in social communities, namely the ideology of legal centralism and other laws. In the ideology of legal centralism, law is a normative rule that is coercive, exclusive, systematic and applies uniformly and can apply top down. Meanwhile, other laws such as local law, in fact, exist in society are hierarchically under the law and state institutions are neglected by interests.

Thus the ideals of social justice in Pancasila should be realized through an independent economy, justice, sustainable development of a just and humane environment based on mutual assistance efforts and mutual control of the state over important production branches that control the livelihoods of many people, as well as over water, the earth and the natural resources contained therein while continuing to pay attention and make room for private property rights, communal rights of indigenous peoples who have authority over their natural resources. In this way, the fifth precept becomes the theoretical basis for the development of the exploitation of forest resources, especially towards the fulfillment of the state of the rights of indigenous peoples to forests in order to realize the welfare of the people (welfare state).

\section{E. CLOSING}

The basis of philosophy, moral postulates, values contained in the precepts of the Pancasila must always be: a guiding star "for the preparation of legal politics, including for the regulation of exploitation of forest resources in Indonesia based on social justice and humanity. These values must become the principles of law in the preparation of legal products, especially in the forestry sector, which gives space for the existence of indigenous and tribal peoples as an entity. The exploitation of forest resources in Maluku which is rich in natural resources must not only be oriented to the economic aspect, but also needs to pay attention to sustainable socio-cultural and environmental aspects in order to achieve the welfare of the community, especially customary law communities. That is the balance between the three aspects with legal subjects. (the government, HPH permit holders and customary law communities) must be in an equal and harmonious position, that the state cannot intervene in the rights and authority of indigenous and tribal peoples over forests and other resources, but instead serve as protectors and protectors for the realization of people's welfare with justice based on Pancasila.

\section{REFERENCES}

A. Suriyaman Mustari Pide, Hukum Adat, Dulu, Kini, dan Akan Datang, Penerbit Buku Pelita Pustaka, 2009

B. ter Haar Bzn, Beginselen en Stelsel van het Adatrecht, Gronongen, J.B. Wolters. 1950.

B. Arief Sidharta, Refleksi Tentang Struktur Ilmu Hukum, Mandar Maju, Bandung, 2000

Bushar Muhammad, Asas-asas Hukum Adat Suatu Pengantar, cet.ke 11, Pradnya Paramita, Jakarta, 2002

Bagir Manan, Dasar-Dasar Sistem Ketatanegaraan RI Menurut UUD 1945, Makalah dalam Ceramah Ilmiah pada Mahasiswa Pascasarjana Unpad TA 1994/1995, Unpad, Bandung, 3 September 1995

Dominikus Rato, Hukum Adat (Suatu Pengantar Singkat Memahami Hukum Adat di Indonesia) Penerbit laksbang pressindo, Yogyakarta, 2011

, Hukum Adat di Indonesia; Suatu Pengantar, Laksbang Justitia Surabaya, 2014

Eugen Ehrlich, Fundamental Principles of The Sociology of Law, Walter L. Moll trans, 1936

Hans Kelsen, "General Theory of Law and State, Russell \& Russell”, (New York : 1945) hlm. 124, sebagai mana dikutip dalam "Tinjauan Yuridis Kebijakan Tingkat Kandungan Dalam Negeri Dan Pajak Impor Dalam Industri Telepon Genggam Dikaitkan Dengan National Treatment”, Thesis Universitas Kristen Maranatha, hal

Frans Magnis Suseno, Berebut Jiwa BangsaI :Dialog, Perdamaian dan Persaudaraan, Kompas, Jakarta, 2006

Jhon Griffiths, Memahami Pluralisme Hukum, Sebuah Deskripsi Konseptual" dalam Pluralisme Hukum Sebuah Pendekatan Interdisipliner, penerjemah Andri Akbar dkk, Huma, Jakarta, 2005

Lawrence M Friedman, Sistem Hukum Perspektif Ilmu Sosial (A Legal Sistem A Social Science Perspective). Diterjemahkan oleh M. Khozim, Nusa Media, Bandung, 2009

La Ode Angga, M. J. Saptenn, The Formulation Of Green Open Space In The Regional Regulation Of Spatial Planning Of Maluku Province, International Journal Of Scientific \& Technology Research Volume 8, Issue 
10, October 2019 Issn 2277-8616 3370 Ijstr@2019 Www.Ijstr.Org

Maria R. Ruwiastuti; Pembaruan Hukum Agraria Dalam Perspektif Masyarakat Adat, Promosi Hak Menentukan Nasib Sendiri Sebagai Dasar Bagi Konsep Pengakuan holistic Dalam Hukum Nasional; dalam Jurnal Masyarakat Adat, Nomor 01 Tahun 1998

Muhammad Bakri, Unifikasi dalam Pluralisme Hukum Tanah di Indonesia (Rekonstruksi Konsep Univikasi Dalam UUPA), Kertha Patrika, vol 33 No 1, 2008

Otje Salman Soemadiningrat, Rekonseptualisasi Hukum Adat Kontemporer, PT Alumni, Bandung 2002

Paul Schiff Berman, Federalism and International Law Througt the Lens of Legal Pluralism, Missouri Law Review, Vol 7, 2008

Rikardo Simarmata, Pengakuan Hukum Terhadap Masyarakat Adat di Indonesia, UNDP Regional Centre in Bangkok, Jakarta. 2006,

Roeslan Saleh, Pembinaan Cita Hukum dan Penerapan Asas-Asas Hukum Nasional, Pusat Dokumentasi Hukum $B P H N$, Depertemen Kehakiman, Jakarta, 1995.

Soejono Koesoemo Sisworo, Mempertimbangkan Beberaa Pokok Pikiran Pelbagai Aliran Filsafat Hukum Dalam Relasi dan Relevansinya Dengan Pembangunan/Pembinaan Hukum Indonesia, dalam 'Kumpulan Pidato Pengukuhan Guru Besar Fakultas Hukum Universitas Diponegoro, Semarang” dihimpun oleh : Soekotjo Hardiwinoto, Badan Penerbit Universitas Diponegoro, Semarang, 1995

S. Soekanto, Beberapa Permasalahan Hukum Dalam Kerangka Pembangunan di Indonesia, UI-Press, 1983, Jakarta

Sjachran Basah, Eksistensi dan Tolak Ukur Badan Peradilan Administrasi di Indonesia, Cetakan kedua, Alumni, Bandung, 1983

Sony Keraf, Filsafat Lingkungan Hidup Alam Sebagai Sebuah Sistem Kehidupan, Kanisius, 2014

Ter Haar, Asas-asas dan Susunan Hukum Adat, terjemahan oleh K.NGSubekti Poesponoto, Pradnya Paramita, Jakarta, 2001

Yudi Latif, Wawasan Pancasila; Bintang Penuntun Untuk Pembudayaan,Cet I, Mizan Anggota IKAPI, Jakarta, 2018 